\title{
A review on dynamic capacities in strategic management
}

\author{
James O. Ayegba, Zhou Lu Lin
}

\begin{abstract}
A B S T R A C T
Objective: The essence of strategic management in every enterprise is targeted at creating value and adding competitive advantage for food and beverage enterprise. In the rapidly changing and complex environment, dynamic capacities play an important role in achieving and sustaining competitive advantage. The main aim of this article is to identify the nature and components of dynamic capacities that have significant effect on strategic management.

Research Design \& Methods: The research method is based on both theoretical and empirical review of literature. The theoretical review of literature is focusing on dynamic capacities and strategic management.
\end{abstract}

Findings: From the empirical review, it was revealed that dynamic capacities and strategic management are very associated as they are embedded in each other. Also, the organizations should take cognizance of innovation and efficient decision making which are revealed to be critical dynamic capacities that do enhance value creation and competitive advantage (strategic management). The aftermath of this is the inevitability of organizational profit.

Contribution \& Value Added: The organizations should focus on product innovation and efficient decision making to enhance value creation and competitive advantage over their competitors. Future studies may examine the performance of dynamic capacities on enterprise in a technology turbulent situation vis-à-vis the proposition of happenings in the Industry 5.0.

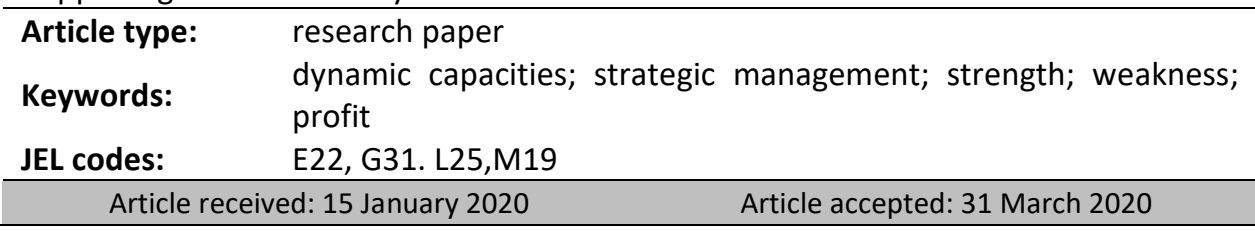

\section{Suggested citation:}

Ayegba, J.O., \& Lin, Z.L. (2020). A review on dynamic capacities in strategic management. International Entrepreneurship Review (previously published as International Entrepreneurship / Przedsiębiorczość Międzynarodowa), 6(1), 47-61. https://doi.org/10.15678/IER.2020.0601.03 


\section{INTRODUCTION}

With the changing dynamics towards the knowledge-based economy, competition in many of the enterprises has become more intense. Several enterprises are espousing different dynamics for marketing to enhance their competitiveness and keep them thriving into the unforeseeable future. Dynamic capacity is the enterprise's ability to methodically solve the challenges of associated with the capacity to predict strengths or opportunities and threats, and be positive about its in-house factors for the purpose of establishing efficient market decisions to transform its resource base.

This concept was at first originated by (Teece, Pisano, \& Change, 1994) and was additionally explored by Teece et al. (1997), where emphasis was made that an enterprise's competitive advantage in a dynamic environment rests on the enterprises' stock of organizational capacities which makes it possible to deliver a constant stream of innovative products and services to customers (Ouyang et al., 2016). Dynamic capacities the development of the company's organizational capacities by changing its resource underlying base (Eisenhardt \& Martin, 2000). Both organizational and dynamic capacities can be called organizational routines, but with different outcomes. Organizational capacities enable services and goods production, whereas dynamic capacities enable development and renewal of organizational capacities.

In view of this, this present study aimed at identifying the nature of dynamic capacities that have significant effect on strategic management based on the review of scholastic studies. It is believed that food and beverage companies in Lagos Nigeria are target of this research. The research method is based on both theoretical and empirical review of literature. The theoretical review of literature focused on dynamic capacities and strategic management.

\section{LITERATURE REVIEW AND THEORY DEVELOPMENT}

\section{Dynamic Capacity (DC)}

The DC concept has been defined in many different ways in various studies. These definitions range from DCs as the ability to meet changes in the external environment (Eisenhardt and Martin, 2000; Lee et al., 2002; Teece et al., 1997; Zahra \& George, 2002), DCs as the ability to achieve superior performance (Griffith \& Harvey, 2001; Gavrea et al., 2011; Zollo \& Winter, 2002), DCs as processes (Eisenhardt \&Martin, 2000), and DCs as the ability to create market change (Eisenhardt \& Martin, 2000; Marsh \& Stock, 2003).

Dynamic capacities (DCs) were developed in order to provide a framework to understand how enterprises achieve and sustain competitive advantage when faced with rapidly changing environmental conditions(Barney \& Clark, 2007; Vanella et al., 2013).It was a framework to inform managerial practice and build theory on enterprise performance, (Teece et al., 1997). Interest in research on dynamic capacities has created a study focus on the processes within an enterprise that are aimed at developing and renewing its resource bases (Di Stefano et al., 2010 Teece, 2012; Teece et al., 1997; Wong, 2013).

The key implication of the concept of dynamic capacities is that enterprises are competing not only in terms of their ability to activate and exploit their existing resources and organizational capacities, but also in terms of their ability to renew and develop 
them. In today dynamic markets, competitive advantage rests on the ability of an enterprise to renew the capacities and constantly develop, that form the basis for products and services offered (C. H. Lin et al., 2008)Dynamic capacities are enterprise assets that are intangible, which involve identifiable and specific processes, stable and learned patterns of organizational routines and collective activities (Ambrosini \& Bowman, 2009; Di Stefano \& Verona, 2010; Eisenhardt \& Martin, 2000).

\section{Strategies Embedded in Dynamic Capacities}

Dynamic capacities are adopted as an enterprise exhibits her character of adapting, renewing, reconfiguring and re-creating resources and core capacities to respond to changing business environments (Wang \&Ahmed, 2007). New strategies emerge with the combination of those resources and capacities (Eisenhardt \& Martin, 2000). These ultimately facilitate the creation of resources that are valuable, rare, inimitable and no substitutable in competing with others. Dynamic capacities thus address a fundamental question of how an enterprise improved performance and builds advantage in a competitive market place (Teece, 2007). (Soriano et al., 2011) state that "dynamic capacities are necessary for identifying practices and business transformation that develop those capacities."(Wilden et al., 2007)Invariably, capability possession, deployment, and upgrading are important for the success of organizations (Luo \& Saltzman, 2000; Silva \& Araújo, 2016).

Teece (2011) proposed the adoption of dynamic capacities framework to help managers lead their enterprises in highly competitive global markets. This functional and useful framework is universal enough to provide guidance in a variety of situations. It is aimed at providing the intellectual structure for both theoretical and applied analysis of strategic management and other concerns of business managers. Dynamic capacities are directed towards aligning the organization with the environment and strategic change (Zahra et al., 2006). They are further seen as the enterprises' capacities to: sense and shape opportunities, seize opportunities, redeploy and reconfigure (create, extend and modify) their resource base (Teece, 2007). Shaping and sensing opportunities and threats involves searching, scanning and exploration activities across technologies and markets (Teece, 2011; K. Z. Zhou \& Wu, 2010).

This obliges the organization to maintain close relationships with customers, suppliers and RandD partners, and to observe best practices in the industry. Seizing opportunities entail the evaluation of existing and emerging capacities, gaining access to investments in relevant designs and technologies that are likely to achieve marketplace acceptance which focuses on taking advantage of opportunities for value creation and competitive advantage (Harreld, et al., 2007; Teece, 2007; Zhuang et al., 2006). The enterprise's capacity to recombine resources and operating capacities reconfigures the resource base which will enable the enterprise to grow, and markets and technologies also to change (,Rothaermel \& Hess, 2007; Teece, 2007).

It is the alignment of the assets of the enterprise to achieve the best fit, in order for strategy to be aligned with structure for effectiveness. This is depicted in the Figure 1.

Teece's (2012) framework of dynamic capacities identifies several universal megatrends that influence the contemporary business enterprises operating in hyper competitive environments. This is against the backdrop of the traditional economic mode where competitive advantage is predicated on economies of scale and scope. Other basis for competitive advantage not related to economies of scale is the generation, ownership and 
management of intangible assets. According to him, the idea of intangible assets has risen to overshadow economies of scale in importance as an enabling factor for organizations to exert a competitive edge and sustain a successful position. Intangible assets characterize the ideas and overall intellectual capacity and resource of an enterprise which is utilized to run its business and have a competitive edge. Contrasted with tangible assets which are physical, intangible assets are the ideological tools strategically deployed by managers to enhance its operation and remain competitive (Kihara et al., 2016).

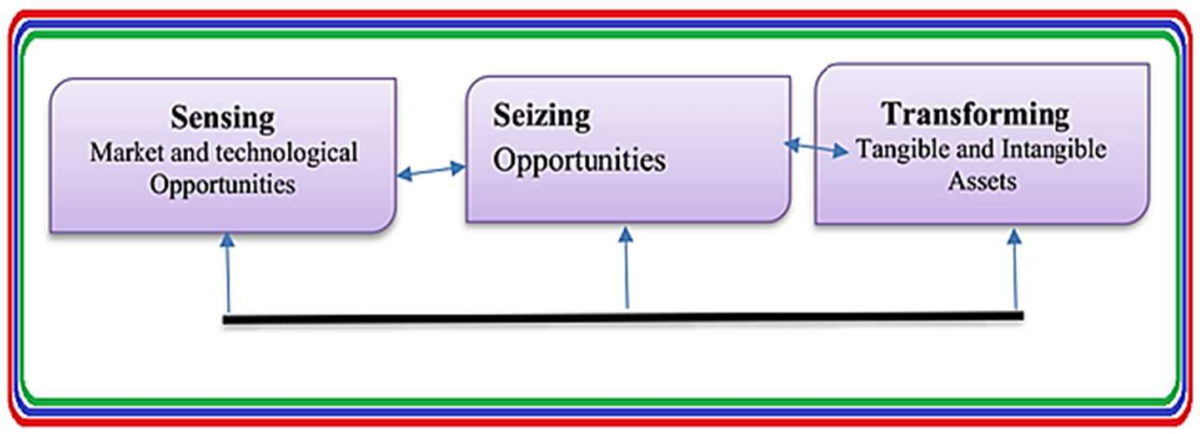

Figure 1. Dynamic capacity

Source: Teece (2007).

Teece (2012) stresses intangible assets as a very powerful class of assets with strong implication for establishing and maintaining competitive edge at the level of the enterprise. He identifies several features of intangible assets as hard to build; difficult to manage; difficult to be traded or transferred; costly to transfer and difficult to specify in a contrast. The implications of these features are that intangible assets are more difficult to procure and access than tangible assets. He further identifies two major classes of intangible assets as technological know-how and business model. He further said that these intangible assets ought not to be used alone but combined with other assets and resources for optimal benefits to the organization.

Since of themselves they are not sufficient to yield value, but combined with other intangible assets or physical assets, they are merged as product to yield value for the customer. On this basis, Teece concludes that ownership of resources or the control of complementary assets is necessary for competitive success. As dynamic capability enhances competition, the comprehensive view of the business environment enables enterprises to survive and achieve their potentials.

Teece et al. (2007) identified that the attainment of sustainable competitive advantage is a function of enterprise's processes, positions and paths. Dynamic capacities are often characterized as idiosyncratic and unique processes that emerge from individual enterprises with path-dependent histories (Teece et al., 1997). They are identified as complicated routines comprising a variety of processes (Prommaratet al., 2015). They further argued that the competitive advantage of companies lies within their managerial and organizational processes, shaped by specific paths and positions available to them.

Eisenhardt and Martin (2000) perceived dynamic capacities as basically processes in terms of strategic or organizational routines through which enterprises reconfigure their 
resources to respond to or create market change. As dynamic capacities enable the enterprise to match its internal strengths with external opportunities through the change of internal resources, they ensure long-term advantages (Teece, 2007). Enterprises that lack dynamic capacities accrue only short-term benefits from their current resource configuration, which may fail to meet market requirements in the future. Dynamic capacities are at the top of many scholars' research agenda owing to the increasing importance of dynamic market environments in the real world (Daniel \& Wilson, 2003; Salvato, 2003; Zott, 2003).

\section{MATERIAL AND METHODS}

The research method of this study is based on both empirical analysis of literature. It is pertinent to note that the theoretical review of literature focused on dynamic capacities and strategic management.

\section{Empirical Literature Analysis}

Earlier research approaches, like the resource-based view (Barney, 1991; Penrose \& Penrose, 1958), propose matching external organizational opportunities and threats with the internal resources of the company to identify opportunities and risks that will shape unique selling positions. The essence of DCs lies in the emphasis on capacity to renew competencies and to strategically manage internal and external organizational skills, routines and resources as the origin of competitive advantage in changing business environments (Banjongprasert, 2013). Driven by turbulent competition from the 1990s, various enterprises have attempted to identify the approach that drives competitive advantage in line with dynamic markets which is captured in the notion of DCs, it is believed to provide sustainable and superior enterprise performance (Banjongprasert, 2013).

Various literatures reviewed disclose an emerging pattern of what dynamic capacities really are. They are mostly seen as path dependent and intentional processes that are the result of the managerial decision making that has the goal of creating, expanding, or changing enterprise's resource configurations with the intention of achieving a particular end result (Eisenhardt \& Martin, 2000). Though DC and RBV are both sharing the same assumptions, DCs is seen different in two main ways; firstly, RBV being static in nature, is insensitive to the environmental change while DCs is concerned with the changing environment. Secondly, RBV theory's focus is on the best way of utilizing the enterprise's resources bundle, unlike DCs that is focusing on the best way to integrate, renew, reconfigure and recreate the resources bundle. It is against this backdrop that Teece et al. (1997), from the RBV perspective, an enterprise that create wealth through the selection of rational alternative among the potential set of resource bundle.

On the contrary DCs is designed to create wealth for the enterprises operating under rapid technological change environments with the objective of sustaining competitive advantage by changing the resource base. Dynamism can be defined as the dynamic heterogeneity that characterizes the organizational environment (Pratono et al., 2016). This is manifested by the amount of change in technologies, customer preferences and modes of competition in the enterprise's principle industries (Miller \& Singh, 1994). Environmental context can be important to the analysis of resources and performance as diverse environments entail different valuations of resources (Penrose, 1959). Moreo- 
ver, Teece and associates (Teece et al., 1997) expound the meaning of dynamic capacities and their importance for achieving competitive advantage in shifting environments. It is suggested that dynamic capacities are ineffective at providing a basis for sustainable competitive advantage Eisenhardt and Martin (2000). Thus, competitive advantage for the potential for lies in the use of dynamic capacities to create enterprise-specific functional competences that contribute to that advantage.

Researchers accept the existence of several hierarchical levels of dynamic capacities and their multidimensional aspect (Ambrosini \& Bowman, 2009;Eisenhardt \& Martin, 2000; Govender et al., 2002; Teece et al., 1997; Winter, 2003; Zahra et al., 2006). The three (3) capacities levels that are prominent are the higher order capacities, first-order capacities, and zero-order capacities. The zero-order capacities used in the day-to-day processes and operations of enterprises and are often referred to as operational or substantive capacities (Coff \& economics, 2003; Helfatet al., 2007; Wang et al., 2006; Zahra et al., 2006; Zaidi et al., 2011).

In this study, the zero-order capacities identified as enterprise's operations constitute the resource base of the company, together with the resource bundles that the company controls or may access easily (Ambrosini \& Bowman, 2009). These capacities are sought to act in equilibrium as they do not involve any change in how the enterprise operates (Helfatet et al., 2007), they comprise enterprise's operations, such as manufacturing, marketing, or logistics, and define the ways in which the company makes its living without changing any of its existing procedures. For example, the preparation of an annual marketing plan for an existing product constitutes an operational capability. In contrast, the first-order capacities involve changes in ways the company works and interacts with the markets (Winter, 2003).

The first-order capacities modify the elements of the enterprise's operations and enable the introduction of changes in day-to-day activities through deployment and reconfigurations of existing enterprise's assets, that is, the resource base (Collis, 1994; Helfatet al., 2007; Winter, 2003). The first-order capacities are seen as the leveraging dynamic capacities. While the higher-order dynamic capacities have the ability of modifying and regenerating the leveraging capacities to induce deliberate and targeted change in the way a company makes its strategy (Ambrosini \& Bowman, 2009; Winter, 2003; Zahra et al., 2006; Zott, 2003). As the first-order capacities build on the existing resource base, the higher-order capacities are applied in the objective of the extension and the renewal of the resource base. For instance, Winter (2003) calls them game-changing capacities and refers to them as deliberate investments in organizational learning.

They play important roles in sensing and seizing new opportunities and in search and selection of new resources to incorporate them in the resource base of the company. They allow for indirect renewal and enhancement of the enterprise's resource base and without them the leveraging capacities (deploying the existing and available resource base) bear the risk of becoming core rigidities of the company (Ambrosini \& Bowman, 2009). The higher-order capacities manifest through the company's learning practices directed towards the development of innovation in its strategic marketing for a swifter recognition of new market opportunities. It equally manifest through the organizational learning and external knowledge absorption (Ambrosini \& Bowman, 2009; Cohen \& Levinthal, 1990; 
Winter, 2003; Zahra et al., 2005), creating network-based opportunities though the relational capability (Capaldo, 2007; Kale \& Singh, 2007)), and developing decision-making processes through dynamic managerial capacities (Adner \& Helfat, 2003; Winter, 2003) and reside within the company's structure.

Regarding the components of DCs, Wang and Ahmed (2007) identified three component factors which reflect the common features of DC's across enterprises, that is, the absorptive capability and innovative capacity, adaptive capacity. Wang and Ahmed (2007) defined them all. Absorptive capability is the ability to identify and apply external information for commercial means (Cohen \& Levinthal, 1990). The enterprises with higher absorptive capability are well able to learn from partners and transform learned knowledge into competences (Chou, 2005; Gavrea et al., 2011). He further sees innovative capacity as a "enterprises' ability to develop new products or markets".

The argument is that these factors explain the confusion behind how resources and capacities can be used to sustain long term enterprise performance (Wang \& Ahmed, 2007). Additional contributions discuss enablers and antecedents of dynamic capacities. Ambrosini and Bowman (2009) discuss internal factors and external factors as inhibitors and drivers for dynamic capacity.(Talaja \& Horizons, 2013) on the other hand, identified four(4) basic elements of dynamic capacities as new product development capacity, market disruptiveness capacity, new process development capacity, and idea generation capacity.

Idea generation capacity can be explained as the development of new and future ideas for entrepreneurial endeavours. Market disruptiveness capacity refers to the behavior of companies in the context of aggressiveness and persistence in introducing innovation to the market. It indicates the extent to which the company creates the dynamism of the market. New product development capacity is related to the development of new products and services, the quality of new products and services and the variety of new products and services in relation to the largest competitors. New process development capacity refers to the performance of innovation adaptation and process of tackling existing processes with new technology. New product development capability and new process development capacity from the classes made by McKelvie and Davidson (2009) can be seen as parts of innovative capacity considering the definitions from the main authors (Miller \& Cardinal, 1994; Wang \& Ahmed, 2007).

Ambrosini and Bowman (2009) opined that external factors such as the nature of the market and the enterprises' history for example determine the enterprises' ability to react to market fluctuations. While the internal factors such as managerial behaviour, social capital and trust for example determine the organizations ability to develop DC's. (Eriksson, 2014)also argued that the creation of DCs rests on internal and external antecedents. Internal antecedents; structural and social, and external antecedents; environmental, networks and relationships influence the organization ability to develop and sustain DCs (Eriksson, 2014). There is a large variety of available reviews that explains the variables of the DC. DCs consist of several classes of factors that can help determine an enterprise's distinctive competencies. These factors are processes, positions and paths and they can be considered as the main variables for the theory. Essentially these factors explain the enterprise's DCs and the sources of competitive advantage (Brandenburger et al., 1996; Teece et al., 1997). 
Teece et al. (1997) explained in their work that DC are processes shaped by paths and positions, and those processes include integration and co-ordination, learning and reconfiguration. While paths and positions are the external and internal forces enabling and constraining DC. The internal position relates to the company's assets which includes; its stock of technological, financial, complementary, reputational, and structural assets. The external position refers to the enterprise vice versa its institutional environment and its markets. Teece et al. (1997) explain that the company's position will have a bearing on the company's strategic standing and how competitive advantage could be gained. Processes, positions and paths are the main variables of dynamic capacities, they are subsequently discussed further.

Processes describe of doing things in the enterprise. They comprise three roles (Teece et al., 1997) the first role; coordination/integration is considered a static concept and it presents the idea that managers are in charge of coordinating and integrating activities within the enterprise (Teece et al., 1997). The degree to which internal coordination and integration is effective and efficient can explain the difference between an enterprise's failure and success. Evidence shows that the way in which production is organized and managed can determine the differences in enterprise competences (Teece et al., 1997). An example could be Japanese manufacturing companies like Toyota, which are able to maintain competitive positions in global market places through excellent managerial and production practices such as total quality management (Andersen, 2001; Phan et al., 2011).

The second role; learning, is considered to be a dynamic concept and represents a process by which experimentation and repetition aids things to be done better and more quickly (Teece et al., 1997). Learning involves individual skills and it is organizational and the organizational knowledge brings about learning resides in new patterns of interactions that represents successful solutions to particular problems (Teece et al., 1997). The concept of DC's as coordinative management process provides potential for inter-organizational learning. Collaborations and partnerships can be a driver for organizational learning, enabling the recognition of dysfunctional routines as espoused by researchers (Teece et al., 1997). Ambrosini and Martin (2000) further stated that "learning mechanisms, such as repeated practice guides the evolution of DCs because it helps gain a deeper understanding of processes and thus helps develop more effective routines"(Ambrosini et al., 2009, p.29-49).

The third role is the reconfiguration and transformation, presents the enterprise's ability to be aware of the need to reconfigure the enterprises' asset structure, and the ability to transform internal and external assets (Teece et al., 1997). Organizations need to observe markets constantly to detect progressions in technologies and they need to be willing to adapt these progressions in order to achieve best practices (Teece et al., 1997). Karim (2006), found that "organizational structure reconfiguration was a DC because it enables business units to recombine their resources and to adapt to environmental changes, such as changes in customer demand" (El Gizawi, 2014, p. 289).

Paths refer to the alternatives that are strategically available to the organization, its history and path dependencies. Path dependencies explain that where an enterprises' future lies are a function of its current position and its history. The technological opportunities that an enterprise has depend on how fast the industry is evolving and how fast scientific breakthroughs are being made(Teece et al., 1997).

It can be said that these three variables combined comprise the core model of DCs (Teece et al., 1997). The three factors aid the ability to react to market fluctuations 
appropriately and efficiently so as to use resources most efficiently in order to outperform competition. In essence, this can be considered as the main hypothesis of the theory as also stated by(Latif et al., 2018), that DCs have a positive impact on competitive advantage.

The argument behind this idea is that these factors can only provide competitive advantage if they are based on a collection of routines, skills and complementary assets that are difficult to imitate and replicate. The ease of imitation can determine the sustainability of competitive advantage. As discussed earlier, usually these enterprise specific assets cannot be bought, implying that they are embedded within enterprises which limit imitation, making it unique to an enterprise; it enables the enterprise to achieve a competitiveness (Ahmad, Othman, \& Lazim, 2014; Teece et al., 1997).

Eisenhardt and Martin (2000) posit that dynamic capability processes comprise specific and identifiable routines which have been researched widely. They suggested several processes that are used as examples of dynamic capacities, such as product development, which combines various skills in cross-functional teams; strategic decision making, which entails pooling of diverse business, functional and personal expertise; and alliance and acquisitions routines, which comprises new resources, before and after acquisition routines and many others. In order to study in an integrated way, the impact of DC on company performance it is useful to abstract from specific processes and routines and to consider broader composite dimensions.

Coordination processes interface and connect single routines through communication, task assignment, scheduling and other related activities. According to Teece et al. (1997) the lack of efficient coordinating and combining of different tasks and resources may explain why apparently changes technology have obvious effects on incumbent company and competitive positions in the market. Capability to learn can be conceived of as a main means of attaining renewal strategically. Renewal necessitates organizations to explore and learn new ways while at the same time exploit what they have already learned(Zhou et al., 2020).

Learning is an essential process which through experimentation and repetition leads to the better and quicker resolution of specific problems and at the same time enables the company to see new opportunities in production. Learning processes are multi-level and dynamic (Teece et al., 1997). Although innovative ideas and insight may occur to individuals, but with individually generated knowledge shared within the organization's context, it will be institutionalized as an organizational artefact.

Dynamic capacities have also been found to be an important part in the product innovations and advanced uses of technology in different organizations. It can be realized that the focuses of dynamic capability on the changing needs of both the company as well as its customers and prepares an enterprise accordingly to face the challenges encountered due to the changing business environment. In other words, the concepts of DC help enterprises to adapt to the changes in the business environment. When dynamic capacities (DC) are involved in product technological and innovation changes, the enterprises also get assisted through the solutions available to technical problems and implementation of new processes and techniques (Afuah, 2002; Shylesh et al., 2010;Zhang, 2007)

The greater need and importance of dynamic capacities arise owing to the constant changes that are prevailing in the business environment. Marketing capacities have been 
found to have a great positive influence on the economic performance of an organization in the global market.(K.-W. Lin \& Huang, 2012) conducted a study on the significance of the dynamic capacities as observed in relation to company performances, enterprise networking and accomplishments of objectives and goals, it may be drawn as a conclusion that DC have a major role to play in the organizational management where the managers and leaders are facilitated in their decision making towards organizational success.

DC can be observed as focusing on various aspects of an enterprise dealing with technological advances and product innovations, handling and facing challenges from the changing business environment as well as improving the performance of the enterprise as a whole. The development of different propositions also reflects the increasing importance of dynamic capacities in organizations that managers are integrating in their strategic management practices all the more from before.

\section{FINDINGS}

Following basic characteristics of the dynamic capacities stand out: dynamic capacities are enterprise-specific, which means solutions to enterprise issues are purposefully carried out by human activity. The solutions are created inside the enterprise, built rather than bought in the market. DCs can be acquired over time on the basis of experience, investments made and knowledge accumulated.

This way, the enterprise is able to react in a timely fashion to the new opportunities and threats arising from the environment and also create external and internal change. Managing the dynamics of the competitive advantage (updating, safeguarding, creation and if needed, dismantle of existing competitive advantage) is realized through resource base modification. This has effect on company performance indirectly, but the impact is not often positive. It is can likewise affect enterprise's performance negatively providing that dynamic capacities have been inadequately developed. Its direct impact on the company's economic performance as their creation, usage generates expenditure and development.

Therefore, in order to achieve the organizational targets, DC should be identified whereas benefits, forecast and collectable costs shall be compared and evaluated; dynamic capacities are unique and inimitable of any business entity or organization. Uniqueness arises from element combination. We can then say that in the key characteristics of organizations DC demonstrate similarities and specifics in terms of details; dynamic capacities seem to be vibrant in turbulent environment though they tend to develop in response to various circumstances, not just environmental changes. They ensure the long-term survival of the company and its progress(Eliasson et al., 2006).

\section{CONCLUSIONS}

The concept of DCs has gained popularity among scholars in the strategic management field. The main objective of DCs is not just to achieve competitive advantage but most importantly is to sustain the competitive advantage under challenging environment. It is a high order-capability usually in the form of intangible (processes / skills / routines / capacities) assets. The intangible processes/skill/routines/capacities can only be the 
source of DCs when they are valuable, rarely available in the market, difficult-to-duplicate by competitors, and non-substitutable that grows from path dependency and heterogeneity between enterprises.

The field of strategic management is essentially concerned with how enterprises generate and sustain competitive advantage, while the dynamic capacity perspective emphasizes on improving the capacity of organizations facing rapidly changing environment to create new resources, renew its mix resource. It acknowledges that "the beliefs about organizational evolution and its top management team are fundamental in developing dynamic capacities". With respect to the policy implication, the organizations should focus on product innovation and efficient decision making to enhance value creation and competitive advantage over their competitors. Future studies may examine the performance of dynamic capacities on enterprise in a technology turbulent situation vis-à-vis the proposition of happenings in the Industry 5.0.

\section{REFERENCES}

Acikdilli, G., \& Ayhan, D. Y. (2013). Dynamic capabilities and entrepreneurial orientation in the new product development. International Journal of Business and Social Science,4(11), 144-150.

Adeniran, A. O., \& Olorunfemi, S.O. (2020). The essence of knowledge management in the air transportAdner, R., \& Helfat, C. E. J. S. m. j. (2003). Corporate effects and dynamic managerial capabilities. Strategic Management Journal, 24(10), 1011-1025. Afuah, A. (2002). Mapping technological capabilities into product markets and competitive advantage: the case of cholesterol drugs. Strategic Management Journal, 23, 171-179.

Ahmad, N., Othman, S. N.,\& Lazim, H. M. (2014). A review of technological capability and performance relationship in manufacturing companies. International Symposium on Technology Management and emerging technologies (ISTMET 2014).

Ambrosini, V., \& Bowman, C. (2009). What are dynamic capabilities and are they a useful construct in strategic management? International Journal of Management Reviews, 11(1), 29-49.

Andersen, T. J. (2001). Information technology, strategic decision making approaches and organizational performance in different industrial settings. Journal of StrategicInformation Systems, 10, 101-119.

Ayegba, J. O. (2015). Impact of Transformational Leadership Style on Organisaitional Productivity:A Case Study Of Julius Berger Construction Company Abuja.Jiangsu University library.

Ayegba, J. O. (2020). 'The Effect of Enterprise Networks on Company Performance Through A Mediating Function of Dynamic Capacities'. Jiangsu University library. https://orcid.org/my-orcid

Bahadir, S. C., Bharadwaj, S., \& Parzen, M. (2009). A meta-analysis of the determinants of organic sales growth. International Journal of Research in Marketing, 26(4), 263-275.

Banjongprasert, J. (2013). An empirical investigation of dynamic capabilities at the individual level: The context of new service development. A PhD Thesis of the Faculty of Humanities of the University of Manchester.

Barney, J. B. (1991). Firm resources and sustained competitive advantage. Journal of Management, $17,99-120$.

Barney, J. B. (2001). Is resource-based "view" a useful perspective for strategic management research? Yes. Academy of Management Review, 26(1), 41-56.

Barney, J. B., \& Clark, D. N. (2007). Resource-based theory: Creating economic rents and competitive advantage. Oxford University Press. 
Barreto, I. (2010). Dynamic capabilities: A review of past and an agenda for the future. Journal of Management, 36(1), 256-280.

Barrett, H., \& Weinstein, A. (1999). The effect of market orientationad and organizational flexibility on corporate entrepreneurship. International Journal of Psychology and Behavioural Research, 3(3), 198-210.

Brandenburger, A. M., \& Stuart, H. W. (1996). Value-based business strategy. Journal of Economics and Management Strategy, 5, 5-24.

Borch, O. J. (2004). Building dynamic capabilities for strategic entrepreneurship in SMEs. NCSB 2004 Conference, 13th Nordic Conference on Small Business Research, 1-24.

Bowen, F. E., Rostami, M., \& Steel, P. (2010). Timing is everything: A meta-analysis of the relationships between organizational performance and innovation. Journal of BusinessResearch, 63(11), 1179-1185.

Capaldo, A. J. S. m. j. (2007). Network structure and innovation: The leveraging of a dual network as a distinctive relational capability. Strategic Management Journal, 28(6), 585-608.

Coff, R. W. J. M., \& economics, d. (2003). The emergent knowledge-based theory of competitive advantage: an evolutionary approach to integrating economics and management. Managerial and Decision Economics, 24(4), 245-251.

Da Silva, H. C., \& Araujo, M. A. (2016). Emerging strategies and hypercompetitive environments to micro and small companies of information technology. American International Journal of Contemporary Research, 6(4), 83-69.

Daniel, E., \& Wilson, H. N. (2003). The role of dynamic capabilities in business transformation. European Journal of Information Systems, 12(4), 282-96.

Danneels, E. (2002). The dynamics of product innovation and firm competences. Strategic Management Journal, 23, 1095-1121.

Di Stefano, G., Peteraf, M., Verona, G. J. I., \& change, c. (2010). Dynamic capabilities deconstructed: A bibliographic investigation into the origins, development, and future directions of the research domain. Industrial and Corporate Change, 19(4), 1187-1204.

Eisenhardt, K. M., \& Martins, J. A. (2000). Dynamic capabilities: What are they? StrategicManagement Journal, 21, 1105 - 1121.

El Gizawi, N. (2014). The dynamic capabilities theory: assessment and evaluation as a contributing theory for supply chain management. University of Twente.

Eliasson, J., \& Mattsson, L.-G. (2006), Equity effects of congestion pricing: Quantitative methodology and a case study for Stockholm, Transportation Research Part A. Policy and Practice, 40(7), 602-620.

Eriksson, T. J. S. j. o. m. (2014). Processes, antecedents and outcomes of dynamic capabilities. Scandinavian Journal of Management, 30(1), 65-82.

Gavrea, C., Ilies, L., \& Stegerean, R. (2011). Determinants of organizational performance: The case of Romania. Management and Marketing Challenges for the Knowledge Society, 6(2), 285-300.

Griffith, D. A., \& Harvey, M. G. (2001). A resource perspective of global dynamic capabilities. Journal of International Business Studies, 32(3), 597-606.

Harreld, J. B., O'Reilly III, C. A., \& Tushman, M. L. (2007). Dynamic capabilities at IBM: Driving strategy into action. California Management Review, 49(4), 21-43.

Helfat, C. E., \& Peteraf, M. A. (2003). The dynamic resource-based view: capability lifecycles. Strategic Management Journal, 24(10), 997-1010.

Helfat, C. E., Finkelstein, S., Mitchell, W., Peteraf, M., Singh, H., \& Winter, D. (2007). Dynamic capabilities: understanding strategic change in organizations. Blackwell. 
Kale, P., \& Singh, H. (2007). Building firm capabilities through learning: the role of the alliance learning process in alliance capability and firm-level alliance success. Strategic Management Journal, 28(10), 981-1000.

Karim, S. (2006). Modularity in organizational structure: The reconfiguration of internally developed and acquired business units. Strategic Management Journal, 27(9), 799-823.

Kihara, A. S., Ngugi, P. K., \& Ogollah, K. (2016). Influence of dynamic capabilities on performance of large manufacturing firms in Kenya. International Journal of BusinessStrategy, 2(1), 106-126.

Latif, Z., Latif, S., Ximei, L., Pathan, Z. H., Salam, S., Jianqiu, Z. J. T., \& Informatics. (2018). The dynamics of ICT, foreign direct investment, globalization and economic growth: Panel estimation robust to heterogeneity and cross-sectional dependence. Telematics and Informatics, 35(2), 318-328.

Lee, J., Lee, K., \& Rho, S. (2002). An evolutionary perspective on strategic group emergence: A genetic algorithm-based model. Strategic Management Journal, 23(7), 727-746.

Li, T., \& Calantone, R. J. (1998). The impact of market knowledge competence on new product advantage: Conceptualization and empirical examination. Journal of Marketing, 62(4), 13-29.

Li, Y., Su, Z., \& Liu, Y. (2010). Can strategic flexibility help firms profit from product innovation? Technovation, 30(5-6), 300-309

Lin, K.-W., \& Huang, K.-P. (2012). Dynamic capability and its effects on firm performance. American Journal of Applied Sciences, 9(1), 107.

Marsh, S. J., \& Stock, G. N. (2003). Building dynamic capabilities in new product development through inter temporal integration. Journal of Product Innovation Management, 20(2), 136-48.

McEvily, S. K., Eisenhardt, K. M., \& Prescott, J. E. (2004). The global acquisition, leverage, and protection of technological competencies. Strategic Management Journal, 25,713 - 722.

Miller, C. C., \& Cardinal, L. B. (1994). Strategic planning and firm performance: A synthesis of more than two decades of research. Academy of Management Journal, 37(6), 1649-1665.

Osisioma, H. E., Nzewe, H. N., \& Mgbemena, I. C. (2016) Dynamic capabilities and performance of selected commercial banks in Akwa, Anambra State, Nigeria. EuropeanJournal of Business and Social Sciences, 4(10), 98-110.

Penrose, E. (1959). The theory of the growth of the firm. Wiley.

Phan, A. C., Abdallah, A. B., \& Matsui, Y. (2011). Quality management practices and competitive performance: Empirical evidences from Japanese manufacturing companies. International Journal of Production Economics, 133, 518-529.

Pratono, A. H., Al-Mashari, M., \& Del Giudice, M. J. B. P. M. J. (2016). Strategic orientation and information technological turbulence: Contingency perspective in SMEs, Business Process ManagementJournal, 22(2), 1-16.

Prommarat, P., Pratoom, K., \& Muenthaisong, K. (2015). A conceptual model of strategic organizational flexibility capability and business survival. Academy of Strategic Management Proceedings. Jordan Whitney Enterprises, Inc.

Rindova, V.P., \& Kotha, S. (2001). Continuous 'morphing': competing through dynamic capabilities, form, and function. Academy of Management Journal, 44, 1263-1278.

Rothaermel, F. T., \& Hess, A. M. (2007). Buidling dynamic capabilities: Innovation driven by individual-, Firm-, and network effects. Organisation Science, 18 (6), 898-921.

Salvato, C. (2003). The role of micro-strategies in the engineering of firm evolution. Journalof Management Studies, 40, 83-108. 
Silva, H., \& Araújo, M.A.V.. (2016). Emerging strategies and hypercompetitive environments to micro and small companies of information technology. American International Journal of Contemporary Research, 6(4), 83-89.

Teece, D. J. (2007). Explicating dynamic capabilities: The nature and micro foundations of sustainable enterprise performance. Strategic Management Journal, 28(13), 1319-1350.

Teece, D. (2009). Dynamic capabilities and strategic management: Organizing for innovationand growth. Oxford University Press.

Teece, D. J. (2012). Dynamic capabilities: Routines versus entrepreneurial action. Journal of Management Studies, 49(8), 1395-1401.Teece, D. J., Pisano, G., \& Shuen, A. (1997). Dynamic capabilities and strategic management. Strategic Management Journal, 18(7), 509-533.

Wang, C. L., \& Ahmed, P. K. (2007). Dynamic capabilities: A review and research agenda. International Journal of Management Reviews, 9(1), 31-51.

Wang, Y., Lo, H., Zhang, Q., \&Xue, Y. (2006). How technological capability influences business performance: An integrated framework based on the contingency approach. Journal of Technology Management in China, 1(1), 27-52.

Winter, S. (2003). Understanding dynamic capabilities. Strategic Management Journal, 24, 991 - 995.

Zaidi, M. F. A., \& Othman, S. N. (2011). Understanding dynamic capability as an ongoing concept for studying technological capability. International Journal of Business andSocial Science, 2(6), 224234.

Zahra, S. A., Sapienza, H. J., \& Davidson, P. (2006). Entrepreneurship and dynamic capabilities: A review, model and research agenda. Journal of Management Studies, 43(4), 917-955.

Zhang, M. J. (2007). IS support for top managers' dynamic capabilities, environmental dynamism, and firm performance: An empirical investigation. Journal of Business andManagement, 13(1), 57-77.

Zhou, K. Z., \& Wu, F. (2010). Technological capability, strategic flexibility, and product innovation. Strategic Management Journal, 31, 547-561.

Zhuang, Y., \& Lederel, A. L. (2006). (2006). A resources-based view of electronic commerce. Information and management, 43, 251- 261.

Zott, C. (2003). Dynamic capabilities and the emergence of intra-industry differential firm performance: Insight from a simulation study. Strategic Management Journal, 24, 97-125. 


\section{Authors}

The contribution share of authors is equal and amounted to $50 \%$ each of them.

\section{James Onuche Ayegba}

PhD in Strategy and Marketing (2020, Jiangsu University, China); MBA degree in Human resourceManagement (Major) of the company (2015, Jiangsu University, China); Bachelor of Science (Bsc) (2006, Ahmadu Bello University, Zaria, Nigeria). His research interests include small and medium-sized enterprises (SMEs), electronic commerce, human resource management.

Correspondence to: Dr. James Onuche Ayegba, Jiangsu University, School of Management, Xuefu Road 301, 212013 Zhenjiang, China, e-mail: 5103150216@stmail.ujs.edu.cn

ORCID (1) http://orcid.org/0000-0001-6127-4353

\section{Zhou Lu Lin}

$\mathrm{PhD}$ holder in economics and lecturer at the Department of Health and Economics Management Science and Engineering, Faculty of Management and Finance, Jiangsu University, Zhenjiang Jiangsu Province Post Code 212013 China. Professor. Zhou specialises in economics and international economics.

Correspondence to: zll62@ujs.edu.cn or zll62@126.com

ORCID (1) http://orcid.org/0000-0002-5266-2191

\section{Acknowledgements and Financial Disclosure}

The authors would like to thank the anonymous referees for their useful comments, which allowed to increase the value of this article.

\section{Copyright and License}

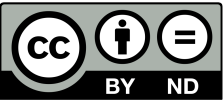

This article is published under the terms of the Creative Commons

Attribution - NoDerivs (CC BY-ND 4.0) License http://creativecommons.org/licenses/by-nd/4.0/

Published by Cracow University of Economics - Krakow, Poland

The journal is co-financed in the years $2019-2020$ by the Ministry of SciRepublic of Poland 
